\section{Influence of a physical activity program on the use of Primary Care services in the city of Rio Claro, SP}

Influência de um programa de exercícios físicos no uso de serviços de saúde na Atenção Básica de Saúde do município de Rio Claro, SP

Andrea Elisa Donovan Giraldo ${ }^{1}$

Grace Angélica de Oliveira Gomes ${ }^{1,2}$

Thais Helena Sayegh Serafim ${ }^{1}$

Lucas Pilla Zorzeto ${ }^{1}$

Diogo Cestari de Aquino ${ }^{1}$

Eduardo Kokubun

\begin{abstract}
The prevention and control of chronic non-communicable diseases, promoted by the regular practice of physical activity, can improve the health status of individuals, and this can reduce government spending and the use of healthcare services. The aim of this study was to investigate the influence of physical activity practice on the use of Primary Care services. Twenty-six women enrolled in a physical activity program held in Primary Care units located in the city of Rio Claro, state of São Paulo, participated in this study. A questionnaire was administered to the women who participated in the program from 2009 to 2011, containing questions regarding participation in the program, health conditions, and participants' perceptions concerning the use of healthcare services related to medical appointments, medications, diseases/complaints and hospitalizations, in the moments before and after the enrolment in the program. A descriptive and comparative analysis was carried out, in which confidence interval analysis for means and frequencies was used, with $95 \%$ confidence intervals. After starting the program, there was an improvement in the participants' health perception, as well as reports of decrease in the number of visits to the healthcare unit, in the number of blood pressure measurements, in uncontrolled blood pressure and blood glucose. On the other hand, the number and dose of drugs remained the same, as well as the number of diseases/complaints and the number of blood glucose measurements. The practice of physical exercises offered by the program contributed to improve the levels of perceived health and to reduce the use of the healthcare services.
\end{abstract}

\section{Keywords}

Physical Activity; Primary Care; Use of Healthcare Services.

\section{Resumo}

A prevençẫo e o controle das doenças crônicas não transmissiveis adquiridos com a prática regular de atividade física podem contribuir na melhoria da saúde dos individuos, o que pode reduzir o uso dos serviços de saúde e os gastos do governo. O objetivo do estudo foi verificar a influência da prática de exercícios físicos no uso dos serviços de saúde na Atenção Básica de Saúde (ABS). Participaram do estudo 26 mulheres de um programa de exercícios físicos em unidades de saúde da ABS do município de Rio Claro-SP.Foi aplicado um questionário com as participantes do programa de 2009 a 2011, contendo questóes referentes à participação no programa,condiçôes de saúde, percepção dos participantes em relação ao uso dos serviços de saúde sobre consultas médicas, medicamentos, doenças/queixas e internações, no momento anterior e posterior ao ingresso no programa. Foi realizada análise descritiva e de comparação, na qual foi utilizada a análise por intervalo de confiança para médias e frequências, sendo este de $95 \%$. Após iniciar no programa, houve melhora da percepção de saúde das participantes, bem como relatos de diminuição do número de visitas à unidade de saúde, do número de medidas da pressão arterial, do descontrole da pressão arterial e da glicemia. Houve também manutenção do número e da dose de medicamentos, do número de doenças/queixas e do número de medidas da glicemia. A prática de exercícios físicos oferecida pelo programa contribuiu para melhora nos níveis de saúde percebida e para diminuição do uso dos serviços de saúde.

\section{Palavras-chave}

Atividade Física; Atenção Básica de Saúde; Uso de serviços de saúde.
Rev Bras Ativ Fis Saúde p. 186-196 DOI:

http://dx.doi.org/10.12820/rbafs.v.18n2p186

1 Departamento de Educação Física, Universidade Estadual Paulista, Núcleo de Atividade Física, Esporte e Saúde, Rio Claro, São Paulo.

2 Departamento de Gerontologia, Universidade Federal de São Carlos, São Carlos, São Paulo. 


\section{INTRODUCTION}

The world has been watching a significant increase in several chronic non-communicable diseases (NCD) such as cancer, diabetes mellitus and hypertension ${ }^{1}$. In Brazil, these diseases are responsible for $72 \%$ of deaths and for the high number of hospitalizations ${ }^{2}$. The complications caused by diabetes and hypertension constitute the first cause of hospitalization in Brazil's public health system; additionally, they are related to the development of other chronic diseases ${ }^{3}$. Concerning the Brazilian economy, it has been demonstrated that, between 2006 and 2015, Brazil will have a loss of 4.18 billion dollars referring to expenditures on diabetes, cardiovascular diseases and strokes ${ }^{4}$.

Inadequate habits such as smoking, inappropriate feeding practices and physical inactivity are considered important causes of $\mathrm{NCD}^{2}$. Physical inactivity, for example, can increase up to four times the chance of acquiring an NCD and has been identified as the fourth largest risk factor for mortality in the world, resulting in $6 \%$ or 3.2 million of the world's deaths ${ }^{1,5}$. However, a significant percentage of the population is insufficiently active. In Brazil, for example, the prevalence of physical inactivity is $14 \%$, and only $30.3 \%$ of the subjects have the habit of performing leisure-time physical activity ${ }^{6}$. The determinants in physical activity include sociodemographic characteristics, presence of disabilities, lack of time or company, and lack of suitable sites near the residences, among others ${ }^{7}$.

In addition to affecting the subjects' quality of life, physical inactivity can generate an unfavorable economic impact on the public healthcare system. Studies have shown that NCD prevention and control that is achieved with the regular practice of physical activity can contribute to reduce the use of healthcare services; consequently, it can contribute to decrease health expenditures ${ }^{8,9}$.The high number of hospital admittances and long hospitalization periods present a high cost to the government and can be minimized by actions of NCD prevention and control offered in Primary Care. The economic potential of physical activity in Brazil's Sistema Único de Saúde (SUS - National Health System) can vary between 12\% for the utilization of medications and 50\% for NCD hospitalizations, and it has been estimated at $\mathrm{R} \$ 2.2$ million $^{8}$.

The regular practice of physical activity has been pointed by the Brazilian Ministry of Health as one of the health promotion strategies that are capable of collaborating with NCD prevention and control, as well as promoting the population's wellbeing. Interventions concerning physical activity to the community have been implemented in diverse contexts, such as squares, beaches, parks, community centers $^{10,11}$ and also in Primary Care centers ${ }^{12,13}$. These physical activity programs aim to comply with the Ministry of Health's proposals for increasing the population's physical activity level. In addition, they produce positive results in relation to the participants' health perception ${ }^{10}$.

One of the objectives of these physical activity interventions is the development of their participants' health, regarding its physical, mental, emotional and social aspects. In the context in which the activities take place, the participants are benefitted by the occurrence of knowledge exchange and by the development of support and affection, which contribute to the formation of new values, new friendships, new dimensions and new meanings for life ${ }^{14}$. For example, social support interferes positively in people's health ${ }^{15}$ and is inversely associated with the risk of developing coronary artery disease and with mortality rates ${ }^{16}$. Considering 
the benefits of regular physical activity to health, these interventions can trigger a change in their participants' health perception and, thus, influence the demands for the use of healthcare services.

Nevertheless, little is known about the extent to which the use of healthcare services related to NCD control can be changed by physical activity interventions at Primary Care units. Therefore, it is necessary to better understand the degree to which physical activity is capable of modifying such demands within this context. In this sense, this study intends to investigate the influence of physical activity practice on the use of Primary Care services.

\section{METHODS}

This retrospective and cross-sectional study was developed in Primary Care units in the city of Rio Claro, state of São Paulo (Southeastern Brazil). The city of Rio Claro is located in the center-eastern region of the state, with 187,637 inhabitants. It has a flat landscape that favors the practice of physical activities, such as walking and cycling, both in transport and leisure time. Furthermore, the city offers a program of physical exercises in Primary Care that is held at all the healthcare units through a partnership with the Universidade Estadual Paulista-Campus of Rio Claro (UNESP- Rio Claro), even in the absence of a Núcleo de Apoio à Saúde da Familia (NASF - Nucleus for Family Health Support). This project was approved by the Research Ethics Committee (protocol 0746) of UNESP-Rio Claro and all the participants signed an informed consent document.

\section{Study's population}

The researched population was composed of women participating in the Physical Activity Program at healthcare units, residing in the city of Rio Claro (São Paulo), older than 20 years.

\section{Sample selection}

In the 14 Primary Care units that offer the physical activity program, 39 women who were assisted at six Family Health Units and four Primary Care Units were selected. The inclusion criteria were the following: participation in the program for at least six months; a minimum of $60 \%$ of attendance at the classes; and participation in the program between January 2009 and May 2011. Among the selected participants, those who had private healthcare plans were excluded. Thus, of the 39 volunteers, 13 participants were excluded, 11 of them because they already had private healthcare plans and two because they had never used the healthcare units. Thus, the data of 26 participants were analyzed. The healthcare units that were selected were Posto da 29, Jardim das Flores, Novo I, Wenzel, Benjamim, Bom Sucesso, Mãe Preta, Palmeiras, Boa Vista and Vila Cristina.

\section{Programa Saúde Ativa Rio Claro}

The physical activity program in healthcare units is part of the Project "Saúde Ativa Rio Claro" (SARC - Rio Claro Active Health), which aims to increase the level of physical activity of the population of Rio $\mathrm{Claro}^{13}$. This project was materialized through a partnership established between the Municipal Health Foundation and UNESP-Rio Claro, under the coordination and supervision of professors, and with the collaboration of postgraduate students from the Núcleo de Atividade Fisi- 
ca, Esporte e Saúde (NAFES - Physical Activity, Sports and Health Nucleus) of the Physical Education Department. This project is funded by the Ministry of Health, by means of the Municipal Health Foundation and the Pro-Rectorate of Extension, and it is carried out by Physical Education professionals and by under graduate and postgraduate students of UNESP-Rio Claro, who monitor and guide actions in the city during campaigns, events and health lectures, as well as healthy eating programs developed by the municipal government around the city.

The physical activity program has assisted part of the population -individuals who have less opportunities to access this kind of program or who belong to groups that are highly vulnerable to an inactive lifestyle (women, more advanced age groups and people who have low socioeconomic levels) ${ }^{7}$. The majority of them come from middle- and low-income classes, and is older than 50 years. The program was implemented in 2001, initially for diabetic, hypertensive and obese patients enrolled in one Primary Care Unit. Over the years, the physical activity program was extended to the other units of the city, with the aim of assisting a larger portion of the population of Rio Claro and complying with the equity policies recommended in the National Policy for Primary Care ${ }^{17}$.Little by little, neighbors and relatives of the program's participants and people living in the catchment area of the healthcare units, enrolled or not in them, started to participate. Thus, heterogeneous groups were formed, with people of several ages, sometimes without the presence of NCD, so that each one of the healthcare units presents specific characteristics. Safety in the execution of the activities is prioritized due to the heterogeneity of the participants' health status.

The intervention is performed twice a week at the healthcare unit itself, at parking lots, sports courts, schools and public spaces around the units, and assists 20 to 40 users at each healthcare center. Physical Education professionals supervise the exercises, which include stretching, hiking, resistance and recreational exercises, with a total duration of 60 minutes per session and mild to moderate intensity. At the beginning of the class, the participants' blood pressure is measured and the last five minutes are used for providing health tips for the group. Recently, the program has been disseminated through folders, a website, posters hang at the units and by the counseling provided by health professionals, considering that the majority of the participants begin the activities through an invitation received from another participant.

\section{Data collection procedure}

Data collection was carried out in June and July 2011 by an interviewer who had been previously trained to administer the questionnaires. Initially, all the students who met the inclusion criteria were approached, and they were interviewed during the classes. The administration of the questionnaire lasted approximately 15 minutes.

\section{Instruments}

A questionnaire that contained open and multiple choice questions was used. The questions were related to: 1) Sociodemographic characteristics; 2) Participation in the program. Regarding physical activity, there were questions about extra-class physical activity practice and the period of practice in minutes per week; 3) Health - presence or absence of hypertension and Type 2 diabetes mellitus, number of diseases/complaints and perceived health based on the instrument Short-Form Health Survey (SF-36); 4) Use of healthcare units - type of assistance searched 
for at the healthcare unit and frequency of visits to the unit (times/month); 5) Use of medication - number and dose of drugs before and after enrolment in the program; 6) Blood pressure and glycemia - Number of measurements and uncontrolled blood pressure and glycemia (months/time); 7) Hospitalizations- Number and reasons. Data on the use of healthcare services were compared in terms of the moment before and after enrolment in the physical activity program, according to the participants' perception (has not changed, has increased or decreased). This instrument was constructed by NAFES members, with the collaboration of suggestions made by professionals of the healthcare units and Physical Education professionals who work in the physical activity program. A pilot test with other participants of the program was carried out before the conduction of the study, in order to adjust the understanding of the questions.

\section{Statistical analysis}

A descriptive analysis of the data was performed through mean, standard-deviation and absolute and relative frequencies. To compare the initial and final values of the analyzed variables, confidence interval analysis for means and frequencies was used, utilizing a 95\% confidence interval. The statistical software SPSS was employed (version 17.0).

\section{RESULTS}

Table 1 describes the participants' sociodemographic characteristics and data on their participation in the SARC Program. The sample was characterized by middle-aged women $(53.9 \pm 11.7$ years), the majority of them with 4 to 12 years of study (65.4\%). The mean participation in the program was of 23.3 months and the monthly attendance at the classes, $88.7 \%$. The majority of the participants $(73.1 \%)$ practiced physical activities outside the classes given at the healthcare units. Table 2 shows the participants' perception in relation to health variables, use of healthcare units, use of medications and uncontrolled blood pressure and glycemia. The majority of the participants reported that the health variable "improved a lot" after

Table 1 - Sociodemographic characteristics and participation in the program Saúde Ativa Rio Claro, $2011(n=26)$

\begin{tabular}{|c|c|c|c|c|}
\hline & VARIABLES & CATEGORIES & $n(\%)$ & MEAN $( \pm S D)$ \\
\hline \multirow{4}{*}{$\begin{array}{l}\text { Sociodemographic } \\
\text { Characteristics }\end{array}$} & Age (years) & & & $53.9( \pm 11.7)$ \\
\hline & \multirow{3}{*}{ Level of schooling (years) } & Up to 4 & $7(26.9)$ & \\
\hline & & $4-12$ & $17(65.4)$ & \\
\hline & & 12 or more & $2(7.7)$ & \\
\hline \multirow{6}{*}{$\begin{array}{l}\text { Participation in } \\
\text { the program }\end{array}$} & Period of participation (months) & & & $23.3( \pm 6.6)$ \\
\hline & $\begin{array}{l}\text { Time spent to go to the place } \\
\text { where the class is given (minutes) }\end{array}$ & & & $7.2( \pm 4.3)$ \\
\hline & $\begin{array}{l}\text { Frequency of attendance (times/ } \\
\text { month) }\end{array}$ & & & $7.1( \pm 1.1)$ \\
\hline & \multirow{2}{*}{$\begin{array}{l}\text { Physical activity practice beyond } \\
\text { the classes given at the units }\end{array}$} & Yes & $19(73.1)$ & \\
\hline & & No & $7(26.9)$ & \\
\hline & $\begin{array}{l}\text { Duration of extra physical activi- } \\
\text { ty (minutes/week) }\end{array}$ & & & $98.6( \pm 108.4)$ \\
\hline
\end{tabular}

$\mathrm{SD}=$ standard-deviation 
Table 2 - Participants' perception in relation to the variables health, use of healthcare units, use of medications and uncontrolled blood pressure and glycemia, $2011(n=26)$

\begin{tabular}{|c|c|c|c|}
\hline VARIABLES & CATEGORIES & & $\mathrm{n}(\%)$ \\
\hline \multirow{9}{*}{ Health } & \multirow{2}{*}{ Hypertensive } & Yes & $14(53.8)$ \\
\hline & & No & $12(46.2)$ \\
\hline & \multirow{2}{*}{ Diabetic } & Yes & $4(15.3)$ \\
\hline & & No & $22(84.7)$ \\
\hline & \multirow{5}{*}{$\begin{array}{l}\text { Have you noticed that your health } \\
\text { has changed since you enrolled in } \\
\text { the program? }\end{array}$} & It has improved a lot & $20(76.9)$ \\
\hline & & It has improved a little & $6(23.1)$ \\
\hline & & $\begin{array}{l}\text { It has neither improved nor } \\
\text { got worse }\end{array}$ & 0 \\
\hline & & It has got a little worse & 0 \\
\hline & & It has got much worse & 0 \\
\hline \multirow{6}{*}{$\begin{array}{l}\text { Use of health- } \\
\text { care units }\end{array}$} & \multirow{3}{*}{$\begin{array}{l}\text { \#Type of assistance sought for at } \\
\text { the unit }\end{array}$} & Medical consultation & $21(80.8)$ \\
\hline & & To get some medications & $2(7.7)$ \\
\hline & & $\begin{array}{c}\text { To practice physical activ- } \\
\text { ities }\end{array}$ & $1(3.8)$ \\
\hline & \multirow{3}{*}{$\begin{array}{l}\text { Has the frequency of visits to the } \\
\text { unit changed after you enrolled in } \\
\text { the program? }\end{array}$} & It has not changed & 10(38.5) \\
\hline & & It has increased & $3(11.5)$ \\
\hline & & It has decreased & $13(50.0)$ \\
\hline \multirow{9}{*}{$\begin{array}{l}\text { Use of medica- } \\
\text { tions }\end{array}$} & \multirow{3}{*}{$\begin{array}{l}\text { Has the number of medications } \\
\text { changed after you enrolled in the } \\
\text { program? }\end{array}$} & It has not changed & 14(53.9) \\
\hline & & It has increased & $7(26.9)$ \\
\hline & & It has decreased & $5(19.2)$ \\
\hline & \multirow{3}{*}{$\begin{array}{l}\text { Has the number of medications for } \\
\text { hypertension and diabetes changed } \\
\text { after you enrolled in the program? }\end{array}$} & It has not changed & $17(65.4)$ \\
\hline & & It has increased & $6(23.1)$ \\
\hline & & It has decreased & $3(11.5)$ \\
\hline & \multirow{3}{*}{$\begin{array}{l}{ }^{*} \text { Has the dose of the medications } \\
\text { changed after you enrolled in the } \\
\text { program? }\end{array}$} & It has not changed & 16(61.5) \\
\hline & & It has increased & $5(19.9)$ \\
\hline & & It has decreased & $4(15.4)$ \\
\hline \multirow{6}{*}{$\begin{array}{l}\text { Blood pressure } \\
\text { and glycemia }\end{array}$} & \multirow{3}{*}{$\begin{array}{l}\text { Frequency of uncontrolled blood } \\
\text { pressure after enrolment in the } \\
\text { program }\end{array}$} & It has not changed & $10(38.5)$ \\
\hline & & It has increased & $1(3.8)$ \\
\hline & & It has decreased & 15(57.7) \\
\hline & \multirow{3}{*}{$\begin{array}{l}\text { Frequency of uncontrolled glycemia } \\
\text { after enrolment in the program }\end{array}$} & It has not changed & 19(73.1) \\
\hline & & It has increased & 0 \\
\hline & & It has decreased & $7(26.9)$ \\
\hline
\end{tabular}

\#Number of losses $=2 ;{ }^{*}$ Number of losses $=1$.

their enrolment in the program. Regarding the use of healthcare units, medical consultation was the type of assistance that the participants most searched for (80.8\%), and the frequency of visits to the Unit decreased after enrolment in the program. In relation to medication use, the majority of the participants reported that there was no change in the number and dose of drugs after their enrolment in the program. In addition, most of them reported a decrease in uncontrolled blood pressure and that there was no change in uncontrolled glycemia after the beginning of the program.

Table 3 presents the comparison between the moment before and after the enrolment in the SARC Program, through confidence interval analysis for the variables of health perception, use of healthcare units, number of diseases/complaints, number of measurements and uncontrolled blood pressure and glycemia. After enrolment in the program, there was an improvement in the participants' general 
Table 3 - Comparison between the moment before and the moment after enrolment in the program in relation to health perception, use of healthcare units, number of diseases/complaints, and number of measurements/uncontrolled blood pressure and glycemia, 2011 ( $n=26$ )

\begin{tabular}{|c|c|c|c|c|c|c|}
\hline & \multirow[b]{2}{*}{ VARIABLES } & & \multicolumn{2}{|c|}{$\begin{array}{c}\text { BEFORE ENROLLING IN THE } \\
\text { PROGRAM }\end{array}$} & \multicolumn{2}{|c|}{$\begin{array}{c}\text { AFTER ENROLLING IN THE } \\
\text { PROGRAM }\end{array}$} \\
\hline & & & $n(\%)$ & Mean $( \pm S D)$ & $n(\%)$ & Mean $( \pm S D)$ \\
\hline \multirow[t]{5}{*}{ Health } & Health perception* & Excellent & 0 & & $3(11.6)$ & \\
\hline & & Very Good & 0 & & $7(26.9)$ & \\
\hline & & Good & $6(23.1)$ & & $16(61.5)$ & \\
\hline & & Regular & $11(42.3)$ & & 0 & \\
\hline & & Poor & $9(34.6)$ & & 0 & \\
\hline $\begin{array}{l}\text { Number of visits to } \\
\text { healthcare units (times/ } \\
\text { month)* }\end{array}$ & & & & $4.1( \pm 6.2)$ & & $2.4( \pm 3.3)$ \\
\hline \multirow{3}{*}{$\begin{array}{l}\text { Number of diseases/ } \\
\text { complaints }\end{array}$} & & None & $9(34.6)$ & & $6(23.1)$ & \\
\hline & & 1 & $8(30.8)$ & & $13(50.0)$ & \\
\hline & & 2 or more & $9(34.6)$ & & $7(26.9)$ & \\
\hline \multirow[t]{4}{*}{$\begin{array}{l}\text { Blood pressure and } \\
\text { glycemia }\end{array}$} & $\begin{array}{l}\text { Number of blood pressure } \\
\text { measurements at the unit } \\
\text { (times/month)* }^{*}\end{array}$ & & & $3.3( \pm 3.4)$ & & $0.5( \pm 1.1)$ \\
\hline & $\begin{array}{l}\text { Number of glycemia } \\
\text { measurements at the unit } \\
\text { (times/month) }\end{array}$ & & & $2.9( \pm 11.7)$ & & $2.6( \pm 11.7)$ \\
\hline & $\begin{array}{l}\text { Frequency of uncontrolled } \\
\text { blood pressure (times/ } \\
\text { month)* }\end{array}$ & & & $2.4( \pm 3.3)$ & & $0.1( \pm 0.4)$ \\
\hline & $\begin{array}{l}\text { Frequency of uncontrolled } \\
\text { glycemia (times/month)* }\end{array}$ & & & $3.5( \pm 8.4)$ & & $0.6( \pm 1.5)$ \\
\hline
\end{tabular}

$\mathrm{SD}=$ standard-deviation; *There was a difference between the periods before and after enrolment.

health perception, as well as a decrease in the number of visits to the healthcare units. In relation to the variables blood pressure and glycemia, there was a decrease both in the number of blood pressure measurements and in uncontrolled blood pressure/glycemia. After the program, there was no change in the number of diseases/complaints and in the number of glycemia measurements.

In relation to hospitalizations, the descriptive data showed that there was a slight reduction in the number of times in which the participants were hospitalized after the program. Before their enrolment in the program, four hospitalizations were reported, due to surgery, pneumonia, gallbladder complications and uncontrolled blood pressure. After their enrolment in the program, two hospitalizations were reported, due to myocardial infarction and bronchitis.

\section{DISCUSSION}

This study investigated the extent to which a physical activity program held in Primary Care units can influence the demands for the use of healthcare services through the perception of their users. Generally speaking, the present study showed that the SARC Program had positive interferences in its practitioners' use of healthcare services. After enrolment in the program, the participants' health perception improved and the frequency of visits to the Healthcare Unit decreased. Regarding medication use, the number and dose of used drugs remained the same, and this also happened in relation to the number of diseases/complaints after the 
beginning of the program. In comparison with the moment before the beginning of the classes, there was a reduction in the number of blood pressure measurements and also in uncontrolled blood pressure and glycemia after the enrolment in the program. Moreover, the program contributed to the maintenance of the number of glycemia measurements and presented reports on the reduction in the number of hospitalizations.

In view of the fact that a poor health perception is one of the factors that determine the search for Primary Care services ${ }^{18}$, the results of our study point to the importance of physical activity programs in the context of Primary Care, which have been stimulated by national healthcare policies. Studies that assessed the effectiveness of community programs of physical exercises offered in Brazil, such as the Programa Academia da Cidade (City's Health Club Program), offered by the municipal governments of Recife and Aracaju (Northeastern Brazil), have shown that the number of individuals with regular or poor health perception was significantly higher among non-users in comparison with users who participated in the Programs ${ }^{11}$. Corroborating our data, Motl et al. ${ }^{19}$ reported the influence of physical activity practice on health perception, showing that physical exercises contribute significantly to the enhancement of quality of life, physical and mental health, and of the sense of self-efficacy. Compared to sedentary individuals, active people also present higher levels of functional capacity perception ${ }^{20}$, and this represents a fivefold reduction in the mortality risk ${ }^{21}$. The majority of the participants in the physical activity program who used to perceive their health status as regular or poor started to perceive their health levels as good or excellent, which might have contributed to the reduction in the utilization of healthcare services at the studied healthcare units.

Many times, the number of visits to healthcare units for medical consultations or other types of assistance is high due to the fact that some users go to these places only as an alternative of social support when they do not receive attention or adequate family care at home. The regular practice of physical exercises has proved to influence positively the practitioners' psychological and emotional aspects, improving their health and their perception about it. Similarly to other physical activity intervention programs, the SARC program promotes, in addition to the activities themselves, socialization among its participants. According to the scientific literature, social integration can trigger positive effects on humor, self-esteem, self-concept, body image and anxiety levels ${ }^{22}$. Furthermore, social conviviality can improve people's emotional and social wellbeing and contribute to alleviate negative feelings, such as depression and isolation ${ }^{14}$. In this way, the socialization that is promoted by the SARC program may have influenced directly its participants' mental health and may have contributed to reduce the number of visits to the healthcare units after they enrolled in the program, producing a possible decrease in the need of healthcare.

The complications generated by chronic diseases are the main cause of physical disability and of the demand for the utilization of the healthcare system, especially hospitalizations. In our study, there was a trend of improvement in the perception of the conditions of self-reported chronic diseases and a better control of the levels of blood pressure and glycemia. Similarly to our findings, some studies have consistently shown that physical activity practice can promote reductions in blood pressure level ${ }^{23}$ and a better glycemic control ${ }^{24}$, achieving a reduction of up to $25.0 \%$ in the mortality risk for hypertensive individuals and $14.0-19.0 \%$ for dia- 
betic individuals every $1 \mathrm{MET}^{1}$ increase in the aerobic capacity ${ }^{25}$. In joint diseases, the practice of aerobic and resistance exercises has also proved to be efficient to improve functional capacity ${ }^{26}$, which may reduce demands for healthcare services due to complications caused by disability.

Interventions based on physical activity at healthcare units, such as the SARC program, are extremely important for the population. In addition to promoting a responsible and high-quality activity, they offer health tips, in view of the fact that the assisted public has low levels of schooling and difficulties in having access to information. Interventions that provide physical activity counseling have become an interesting and efficient method for health promotion, producing beneficial results concerning behavior changes and increasing participants physical activity levels ${ }^{12}$. Other studies about interventions with counseling in this context have shown that the increase in the subjects' physical activity level and quality of life were the most common results ${ }^{27,28}$. This type of intervention, like the one offered by the SARC, which combines, in the classes, activities and healthcare instructions, may be efficient to promote participants' adherence and to include new individuals in physical activity practice. As a result, benefits to these users' health are obtained, which might produce, together with other factors, less dependence on healthcare services.

Individuals with low income, lower levels of schooling and who are older have a greater need to use the healthcare services and a greater tendency to have difficulties in accessing suchservices ${ }^{29}$. At the same time, people with this profile also use Primary Care services with higher frequency. Regarding the frequency of use of healthcare services, when it occurs haphazardly and excessively, it is expensive both to the government and to the individual. Obesity, chronic diseases and their complications produce a large economic impact on health expenditures, especially because they increase the proportion of medications and hospitalizations, a procedure that has a high cost to the government. ${ }^{8,9,30}$. Thus, the participants in the program of physical exercises analyzed here reported that they modified their patterns of use of the Primary Care services, which may have occurred due to the effects of physical exercises. This may bring an economy to the government and better quality of life to the users of healthcare units.

The measurement instrument that was used was a questionnaire administered in the form of an interview. It contained questions about diverse aspects related to the use of the healthcare services. This questionnaire enabled to obtain data that were both qualitative, through the perception of changes in the analyzed variables, and also quantitative, through absolute figures concerning the healthcare services. In addition, this questionnaire's language could be easily understood by the participants and its administration was quick, which showed that the instrument has a good applicability. However, the use of this kind of questionnaire precludes the obtention of complete information and reliable records referring to the use of the healthcare services, which would be achieved through the utilization of medical records, for example. Moreover, the answers about the participants' perception may have been influenced by their memory of the moment in which they enrolled in the program.

This study had some limitations. The number of evaluated subjects was small, as the program assists a specific portion of the population; additionally, to avoid memory bias, only the women who participated in the program and who were selected in specific years of enrolment in the physical activity group participated

$1 \mathrm{MET}$, Metabolic Equivalent of Task, or simply metabolic equivalent, is a measure of the intensity of aerobic exercise. 
in the study. Furthermore, these data can be generalized neither to other places nor to male individuals, as $95.6 \%$ of the participants in this program are women, which prevented the analysis of data for men. Also, only subjective data were used, involving the individuals' perception about the use of healthcare services. To better understand the role that physical activity plays in the demand for the healthcare system, we suggest that further studies should approach a higher number of participants and use tools that are able to evaluate, in a direct way, the data to be analyzed (for example, medical records), thus enabling actions that are increasingly efficient.

In the present study, it was observed that the practice of physical exercises offered by the SARC program contributed to improve the perceived health levels and to reduce the use of the healthcare services, according to the perception of the programs' participants. This finding is extremely important and corroborates previous studies when it shows that the inclusion of programs that aim to stimulate the practice of physical exercises should be widely used by the National Public Health Policies, as they promote a better quality of life and provide a direct contribution, through the decrease in the demand for the healthcare services.

\section{Acknowledgements}

The authors would like to thank all the participants in the Project "Saúde Ativa Rio Claro" for their collaboration in the interviews, and the Municipal Health Foundation of Rio Claro for the partnership with the Universidade Estadual Paulista and for the contributions to the Project "Saúde Ativa Rio Claro".

\section{Authors' contribution}

All the authors substantially contributed to the writing of the paper. AEDG chose the theme, collected and interpreted the data and wrote the manuscript. GAOG co-supervised the work and collaborated in the design of the proposal and in the writing of the paper. THSS, LPZ and DCA collaborated in the writing and correction of the text and provided a critical analysis of the study. EK coordinated and supervised the study, revised the paper critically and approved the submission of the manuscript. All the authors read and approved the final version of the manuscript.

\section{REFERENCES}

1. Lee IM, Shiroma EJ, Lobelo F et al. Effect of physical inactivity on major non-communicable diseases worldwide: an analysis of burden of disease and life expectancy. Lancet 2012; 380:219-229.

2. Schmidt MI, Duncan BB, Silva GA et al. Doenças crônicas não transmissíveis no Brasil: carga e desafios atuais. The Lancet 2011;4:61-74.

3. Ministério da Saúde. Plano de ações estratégicas para o enfrentamento das doenças crônicas não transmissíveis (DCNT) no Brasil 2011-2022. Brasília: Ministério da Saúde. Secretaria de Vigilância em Saúde. Departamento de Análise de Situação de Saúde, 2011.

4. Abegunde DO, Mathers CD, Adam T et al. The burden and costs of chronic diseases in low-income and middle-income countries. Lancet 2007;370: 1929-1938.

5. Warburton ER, Nicol CW, Bredin SSD. Health benefits of physical activity: the evidence. Can Med Assoc J 2006; 174: 801-809.

6. Vigitel. Sistema de Monitoramento de Fatores de Risco e Proteção para Doenças Crônicas Não Transmissíveis por meio de Inquérito Telefônico. Brasil: Ministério da Saúde, 2011.

7. Bauman AE, Reis RS, Sallis JF et al. Correlates of physical activity: why are some people physically active and others not? The Lancet 2012; 380:258-271.

8. Bielemann RM, Knutha G, Hallal PC. Atividade física e redução de custos por doenças crônicas ao Sistema Único de Saúde. Rev Bras Ativ Fís Saúde 2010;15:(1). 
9. Codogno JS, Fernandes RA, Sarti FM et al. The burden of physical activity on type 2 diabetes public healthcare expenditures among adults: a retrospective study. BMC Public health 2011; 11: 275

10. Hallal, PC, Reis RS, Hino AAF et al. Avaliação de programas comunitários de promoção da atividade física: o caso de Curitiba, Paraná. Rev Bras Ativ Fís Saúde 2009;14: 104-114.

11. Hallal, PC, Tenório MC, Tassitano RM et al. Avaliação do programa de promoção da atividade física Academia da Cidade de Recife, Pernambuco, Brasil: percepções de usuários e não-usuários. Cad Saúde Públ 2010;26:70-78.

12. Gomes MA, Duarte MFS. Efetividade de uma intervenção de atividade física em adultos atendidos pela estratégia Saúde da Família: Programa de Ação e Saúde Floripa - Brasil. Rev Bras Ativ Fís Saúde 2008;13:44-56.

13. Nakamura PM, Papini CB, Chiyoda A et al. Programa de intervenção para a prática de atividade física: Saúde Ativa Rio Claro. Rev Bras Ativ Fís Saúde 2010; 15: 128-131

14. Souza DL, Vendrusculo R. Fatores determinantes para a continuidade da participação de idosos em programas de atividade física: a experiência dos participantes do projeto "Sem Fronteiras". Rev Bras Educ Fís Esporte 2010;24:95-105.

15. Uchino BN. Social support and health: a review of physiological processes potentially underlying links to disease outcomes. J Behav Med 2006; 29: 377-387.

16. Rutledge T, Reis SE, Olson M et al. Social networks are associated with lower mortality rates among women with suspected coronary disease: The National Heart, Lung, and Blood Institute sponsored Women's Ischemia Syndrome Evaluation study. Psychosom Med 2004;66: 882-888.

17. Brasil. Política Nacional de Promoção da Saúde. Brasília: Ministério da Saúde, 2006.

18. Sawyer DO, Leite IC, Alexandrino R. Perfis de utilização de serviços de saúde no Brasil. Ciênc Saúde Coletiva 2002; 7: 757-776.

19. Motl RW, McAuley E. Physical Activity, Disability, and Quality of Life in Older Adults.Phys Med Rehabil Clin N Am 2010; 21: 299-308.

20. Netz Y, Wu M-J, Becker BJ et al. Physical activity and psychological well-being in advanced age: a meta-analysis of intervention studies. Psychol Aging 2005; 20(2):272-84.

21. Benyamini Y, Leventhal EA, Leventhal H. Gender differences in processing information for making self-assessment of health. Psychosom Med 2000;62:354-364.

22. Scully D, Kremer J, Meade MM et al. Physical exercise and psychological well being: a critical review. Br J Sports Med 1998; 32: 111-120.

23. Cornelissen VA, Fagard RH. Effects of endurance training on blood pressure, blood pressure-regulating mechanisms, and cardiovascular risk factors.Hypertension 2005; 46:667-675.

24. Balducci S, Zanuso S, Cardelli P, Salvi L, Bazuro A. Effect of high- versus low-intensity supervised aerobic and resistance training on modifiable cardiovascular risk factors in type 2 diabetes; the Italian Diabetes and Exercise Study (IDES). PLoSOne2012;7:e49297.

25. Kokkinos P, Myers J, Doumas $M$ et al. Exercise capacity and all-cause mortality in prehypertensive men. Am J Hypertens 2009;22:735-741.

26. Feinglass J, Song J, Semanik Pet al. Association of functional status with changes in physical activity: insights from a behavioral intervention for participants with arthritis. Arch Phys Med Rehabil 2012;93:172-5.

27. Sabti, Z, Handschin M, Kutlar Joss M et al. Evaluation of a physical activity promotion programin primary care. Family Practice 2010;27:279-84.

28. Eakin EG, Bull SS, Riley K et al. Recruitment and retention of Latinos in a primary care-based physical activity and diet trial: The Resources for Health study. Health Educ Res 2007;22:361-71.

29. Louvison MCP, Lebrão ML, Duarte YAO et al. Desigualdades no uso e acesso aos serviços de saúde entre idosos do município de São Paulo. Rev Saúde Públ 2008;42:733-740.

30. Daviglus ML, Liu K, Yan LL et al. Relation of body mass index in young adulthood and middle age to Medicare expenditures in older age. JAMA 2004;292:2743-9.

$$
\begin{array}{r}
\text { Corresponding author } \\
\text { Andrea Elisa Donovan Giraldo } \\
\text { Rua Dom Francisco de Campos Barreto n¹45, } \\
\text { Nova Campinas, Campinas, São Paulo } \\
\text { Cep: 13092-160Tel: } 19 \text { 32942292Cel: } 19 \\
78060482 \\
\text { E-mail: deagiraldo@yahoo.com.br } \\
\text { E-mail de contato: graceaogomes@yahoo.com.br }
\end{array}
$$

$$
\begin{array}{ll}
\text { Received } & 01 / 05 / 2013 \\
\text { Revised } & 07 / 02 / 2013 \\
& 25 / 02 / 2013 \\
& 12 / 04 / 2013 \\
\text { Approved } & 26 / 04 / 2013
\end{array}
$$

